\title{
ANALISIS FITOKIMIA SENYAWA METABOLIT SEKUNDER EKTRAK KASAR ETANOL DAUN MERANTI MERAH (Shorea leprosula Miq.) DAN SIFAT ANTIBAKTERINYA TERHADAP Staphylococcus aureus DAN Eschericia coli
}

\author{
Sudrajat, Sadani, Sudiastuti \\ Prodi Biologi FMIPA Universitas Mulawarman, Samarinda
}

\begin{abstract}
This study aims to determine the content of secondary metabolites and antibacterial power crude extract copper leaf meranti (Shorea leprosula Miq.) against Staphylococcus aureus and Escherichia coli. Antibacterial power is determined by the size of inhibition zone formed using paper disc diffusion method of Kirby-Bauer. The research design using a completely randomized design (CRD), with a concentration of 6 treatments and 4 replication for each type of bacteria. Variations in the concentration of a given treatment consisting of 0\%, 3.75\%, 7.5\%, 11.25\%, 15\%, and chloramphenicol (positive control). The results shown that crude extract copper leaf meranti (Shorea leprosula Miq.) contain secondary metabolites such as alkaloids, saponins, triterpenoids, flavonoids, phenols and antibacterial power against Staphylococcus aureus and Escherichia coli, with the relatively strong antibacterial category. Anova analysis showed that the value of $F$ count $=41,190$ with sig $=0.000<0.05$, which means that $\mathrm{HO}$ is rejected, in other words, treatment factors meranti copper leaf crude extract with various concentrations of 3.75\%, 7.5\%, 11, 25\%, and $15 \%$. different significantly affect the bacterial inhibition zone for S. aureus. The result same effect shown onE. coli demonstrated the value Fcount $=81,236$ with sig $=0.000$ $<0.05$. These results demonstrate the influence of crude extract of leaf meranticopper very significantly to the growth of bacteria $S$. aureus and E. coli. At S.aureus, treatment concentration of $3.75 \%, 7.5 \%, 11.25 \%$, and $15 \%$ yielding different significant of inhibition zone. In the E.colibacterial, treatment concentration of 3.75\%, 7.5\%, $11.25 \%$, and $15 \%$ yielding different significant of inhibition zone.Best concentration as antibacterial S.aureus and E.coli have been shown on providing the lowest treatment concentration (3.75\%), which shows the power antibacterial properties not significantly different from the concentration on it.
\end{abstract}

Keywords: Leaf of Shorea leprosula Miq, secondary metabolite substance, antibacterial, Staphylococcusaureus, Escherichia coli

\begin{abstract}
Abstrak
Penelitian ini bertujuan untuk mengetahui kandungan senyawa metabolit sekunder dan daya antibakteri ekstrak kasar daun meranti tembaga (Shorea leprosula Miq.) terhadap bakteri Staphylococcus aureus danEscherichia coli.Ukuran daya antibakteri ditentukan oleh zona hambat yang terbentuk menggunakan metode difusi kertas cakram Kirby-Bauer.Rancangan penelitian menggunakan Rancangan Acak Lengkap (RAL), dengan konsentrasi dari 6 perlakuan dan 4 replikasi untuk setiap jenis bakteri.Variasi konsentrasi perlakuan yang diberikan terdiri atas $0 \%, 3.75 \%, 7.5 \%, 11.25 \%, 15 \%$ dan kloramfenikol (kontrol positif). Hasil penelitian menunujukkan bahwa ekstrak kasar daun meranti tembaga (Shorea leprosula Miq.) mengandung senyawa metabolit sekunder seperti alkaloid, saponin, triterpenoid, flavonoid, fenol dan daya antibakteri terhadap bakteri Staphylococcus aureus
\end{abstract}


dan Escherichia coli, dengan kategori antibakteri tergolong kuat.Analisis anava menunjukkan bahwa nilai $\mathrm{F}_{\text {hitung }}=41.190$ dengannilai sig $=0,000<0,05$, yang berarti bahwa $\mathrm{H}_{0}$ ditolak, dengan kata lain faktor perlakuan ekstrak kasar daun meranti tembaga dengan variasi konsentrasi 3,75\%,7,5\%,11,25\%, dan $15 \%$. berpengaruhberbeda secara sangat signifikan terhadap zona hambat untuk bakteri $S$. aureus.Hal yang sama ditunjukkan pengaruhnya terhadap E.coli dengan nilai $\mathrm{F}_{\text {hitung }}=81.236$ dengannilai sig $=0,000<0,05$. Hasil ini menunjukkan adanya pengaruh ekstrak kasar daun meranti termbaga secara sangatsignifikan terhadap pertumbuhan bakteri S. aureus dan E. coli. Pada bakteri Staphylococcus aureus,perlakuan konsentrasi 3.75\%, 7.5\%, $11.25 \%$, dan $15 \%$ menghasilkan zona hambat yangberbeda signifikan. Pada bakteri Escherichia coli, perlakuan konsentrasi 3.75\%, 7,5\%, 11.25\%, dan 15\% menghasilkan zona hambat yang berbeda signifikan. Konsentrasi terbaik sebagai antibakteri S.aureus dan E.coli telah ditunjukkan pada pemberian konsentrasi perlakuan terendah $(3,75 \%)$, yang menunjukkan sifat daya antibakterinya tidak berbeda nyata dengan konsentrasi di atasnya.

Kata Kunci : Daun meranti tembaga (Shorea leprosula Miq.), zat bioaktif, antibakteri, Staphylococcus aureus, Escherichia coli

\section{PENDAHULUAN}

$\begin{array}{lrr}\text { Meranti } & \text { Tembaga (Shorea leprosula } \\ \text { Miq.) } & \text { termasuk } & \text { kelompok } \\ \text { tumbuhanfamilia } & \text { dipterocarpaceae. }\end{array}$ Menurut Sotheeswaran, 1993, dipterocarpaceae merupakan tumbuhan hutan yang menunjukkan sifat resistensinya terhadap serangan biologis. Zat aktif yang terdapat dalam anggota famili ini sangat beragam yang meliputi golongan fenolik, seperti oligostilbenoid, flavonoid, fenil propanoid dan turunan asam fenolat, serta golongan non fenolik yaitu triterpenoid.

Senyawa antibakteri merupakan senyawa yang memiliki kemampuan mencegah terjadinya pertumbuhan dan reproduksi bakteri. Pada tumbuhan, senyawa antibakteri biasanya terdapat pada bagianbagian tanaman seperti daun, ranting, kulit kayu dan bagian-bagian lainnya. Antibakteri digunakan untuk menghilangkan bakteri yang berpotensi membahayakan bagi kesehatan dan bersifat patogen seperti bakteri $S$. aureus dan bakteri E. coli.
Penelitian tentang kandungan senyawa bioaktif yang terdapat pada daun tumbuhan meranti tembaga ( $S$. leprosula Miq.) dan sifatnya sebagai antibakteri belum banyak dilakukan.Penelitian ini bertujuan untuk mengetahui kandungan senyawa metabolit apa saja yang terdapat pada daun tumbuhan meranti tembaga $(S$. leprosula Miq.) dan bagaimana sifatsifatnya sebagai antibakteri terhadap bakteri $S$. Aureus yang mewakili bakteri gram positif dan bakteri $E$. coli yang mewakili bakteri gram negatif dan pada konsentrasi berapa ekstrak kasar daun meranti tembaga yang paling efektif bersifat antibakteri.

Manfaat dilakukannya penelitian ini adalah diharapkan dapat memberikan tambahan ilmu pengetahuan dalam bidang obat tradisional dan digunakan sebagai masukan bagi masyarakat dalam upaya pemanfaatan daun meranti tembaga (S. leprosula Miq.) sebagai sumber bahan antibakteri. 


\section{METODE PENELITIAN}

\section{Bahan Penelitian}

Bahan tumbuhan diambil dari Hutan Kebun Raya Unmul Samarinda.Bahan yang digunakan adalah etanol $95 \%$, aquadest, kloroform-amoniak, dietil eter, $\mathrm{H}_{2} \mathrm{SO}_{4} 2 \mathrm{M}, \mathrm{H}_{2} \mathrm{SO}_{4}$ pekat, $\mathrm{CH}_{3} \mathrm{COOH}$ glasial, $\mathrm{Bi}\left(\mathrm{NO}_{3}\right)_{2} .5 \mathrm{H}_{2} \mathrm{O}, \mathrm{HNO}_{3}$ pekat, $\mathrm{FeCl}_{3} 1 \%, \mathrm{HCl}$ pekat, $\mathrm{KI}$ dan serbuk $\mathrm{Mg}$, biakanbakteri E. coli dan S. aureus, ekstrak daunmeranti tembaga (S. leprosula Miq.), larutan $\mathrm{NaCl} 0.9 \%$, aquades dan media LBA (Luria Bertani Agar ).

\section{Rancangan Penelitian}

Penelitian ini menggunakan Rancangan Acak Lengkap (RAL) terdiri atas 5 perlakuan dan 4 ulangan pada tiap jenis. Perlakuan konsentrasi ekstrak daun terdiri atas

$\mathrm{K}_{+} \quad=$ Kloramfenikol;

$\mathrm{K} 0=$ Aquadest ;

$\mathrm{K} 1=3,75 \%(\mathrm{~b} / \mathrm{v})$;

$\mathrm{K} 2=7,5(\mathrm{~b} / \mathrm{v})$;

$\mathrm{K} 3=11,25 \%(\mathrm{~b} / \mathrm{v})$, dan

$\mathrm{K} 4=15 \%(\mathrm{~b} / \mathrm{v})$

\section{Alat dan Bahan}

Alat yang digunakan dalam penelitian ini adalah parang, blender, timbangan analitik, toples maserasi, gelas ukur, pipet volume, kertas saring, corong, erlenmeyer, alat shaker, aluminium foil, rotary evaporator, spatula, desikator, botol film, corong pisah, batang pengaduk, cawan petri, neraca analitik, spatula, pipet tetes, tabung reaksi, rak tabung, batang pengaduk, kertas saring Whatman no 40, beaker glass, erlenmeyer, water bath, cawan petri, autoclave, laminar air flow, hot plate, timbangan analitik, refrigerator, oven, lemari es, $\mathrm{pH}$ meter, rak tabung reaksi, tabung reaksi, Erlenmeyer, lampu bunsen, jarum ose, pinset, aluminium foil, magnetic stirrer, kertas cakram, mikropipet, yellow tip, blue tip, jangka sorong, kain hitam dan kamera digital.

\section{Preparasi dan Ekstraksi}

Daun meranti tembaga dipisahkan dari ranting-ranting pohon kemudian daun diiris-iris, dikering anginkan selama 5 hari kemudian ditimbang sebanyak 1000 gr dandihaluskan menggunakan blender. Bahan yang dihaluskan kemudian dimaserasi berulang dengan etanol 95\% sebanyak 5 liter selama seminggu. Sehari sekali diaduk dengan batang pengaduk dan jika etanol berkurang maka ditambahkan lagi. Hasil maserasi dishaker selama 24 jam kemudian disaring dengan menggunakan kertas saring dan corong. Sisa ampas kembali diberi etanol $70 \%$ (maserasi ulang sampai ekstraksi berwarna jernih).Kemudian dilakukan pemisahan pelarutnya dengan dilakukan penyaringan dan pelarutnya diuapkan dengan menggunakan rotary evaporator hingga diperoleh ekstrak kasar yang berupa pasta. Dilakukan pengenceran hasil pemekatan larutan tersebut dengan menambahkan aquades untuk dibuat menjadi beberapa konsentrasi yang telah ditentukan.

\section{Teknik Analisis Data}

Data yang dihasilkan dianalisis dengan anava. Jika hasil analisis ragam memberikan hasil yang signifikan, maka analisis dilanjutkan dengan uji jarak berganda Duncan (Duncan Multiple Range Test, DMRT) pada taraf kepercayaan $95 \%$. 


\section{HASIL DAN PEMBAHASAN}

\section{Rendemen dan Hasil Uji Fitokimia}

Berat kering daun meranti tembaga yang telah dihaluskan dan yang digunakan dalam penelitian ini adalah 900 gram, kemudian diekstraksi secara maserasi dengan etanol $95 \%$ dan diperoleh ekstrak pekat atau pasta sebesar 78,08 gr dengan warna hijau pekat kehitam-hitaman. Berat dan hasil rendemen ekstrak kasar daun meranti tembaga disajikan pada Tabel 1.

\section{Hasil Uji Antibakteri}

Hasil analisis data dengan ANAVA menunjukkan bahwa nilai $\mathrm{F}$ hitung = 41.190 dengan nilai sig $=0,000<0,05$, yang berarti bahwa $\mathrm{H}_{0}$ ditolak, dengan kata lain faktor perlakuan ekstrak kasar daun meranti tembaga dengan variasi konsentrasi 3,75\%, 7,5\%, 11,25\%, dan $15 \%$. Berpengaruh berbeda secara sangat signifikan terhadap zona hambat untuk bakteri $S$. aureus.Hal yang sama ditunjukkan pengaruhnya terhadap E.coli dengan nilai $\mathrm{F}$ hitung $=81.236$ dengan nilai sig $=0,000<0,05$. Hasil uji fitokimia terhadap daun Meranti tembaga menunjukkan bahwa dalam ekstrak tersebut mengandung beberapa senyawa metabolit sekunder seperti terlihat pada Tabel 2. Hasil ini menunjukkan adanya pengaruh ekstrak kasar daun meranti termbagasecara sangatsignifikan terhadap pertumbuhan bakteri $S$. aureus dan $E$. coli. Uji lanjut dengan metode Duncan Multiple Range Test pada taraf kepercayaan $95 \%$ disajikan dalam Tabel 3.

Tabel 1. Hasil rendemen ekstrak kasar sampel daun meranti tembaga (S. leprosula Miq.).

\begin{tabular}{cccc}
\hline Sampel & Berat Kering Angin (g) & Berat Ekstrak Kasar (g) & Rendemen (\%) \\
\hline Daun meranti tembaga & 900 & 78,08 & 8,675 \\
\hline
\end{tabular}

Tabel 2. Data hasil uji fitokimia ekstrak kasar daun S. leprosula Miq.

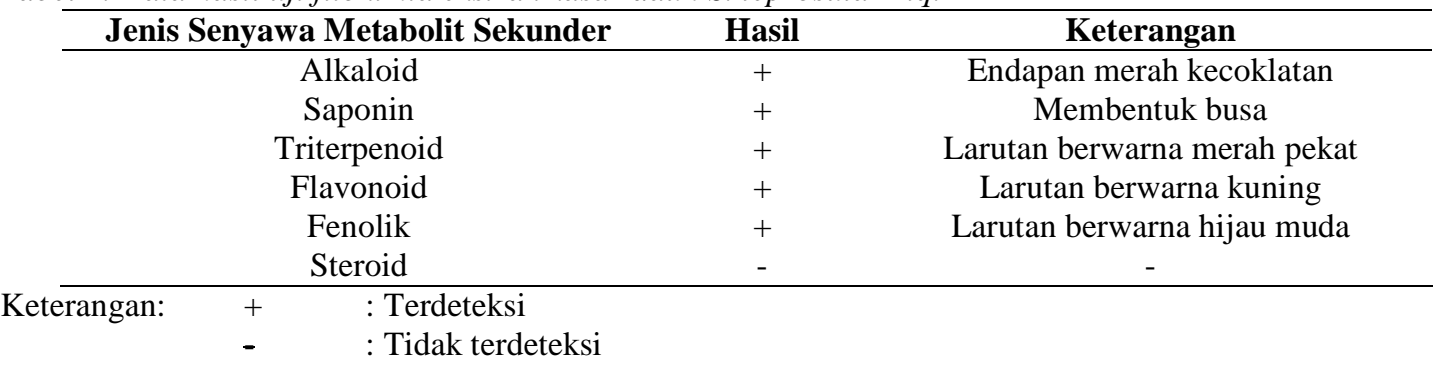

Tabel 3. Hasil Uji Aktivitas Ekstrak Kasar Daun Meranti Tembaga (S. leprosula Miq.) Terhadap Bakteri S. aureus dan E. coli

\begin{tabular}{lcc}
\hline \multirow{2}{*}{ Perlakuan } & \multicolumn{2}{c}{ Rata-Rata Diameter Zona Hambat $(\mathbf{m m})$} \\
\cline { 2 - 3 } $0 \%$ & S. aureus & E. coli \\
$3,75 \%$ & $0.0000^{\mathrm{a}}$ & $0.0000^{\mathrm{a}}$ \\
$7,5 \%$ & $13.1250^{\mathrm{b}}$ & $16.4375^{\mathrm{b}}$ \\
$11,25 \%$ & $14.7500^{\mathrm{b}}$ & $16.4375^{\mathrm{b}}$ \\
$15 \%$ & $16.2500^{\mathrm{b}}$ & $15.3750^{\mathrm{b}}$ \\
Kloramfenikol & $15.5625^{\mathrm{b}}$ & $16.5625^{\mathrm{b}}$ \\
\hline
\end{tabular}

Keterangan: Angka yang diikuti huruf yang sama dalam kolom yang sama tidak berbeda nyata pada uji DMRT taraf kepercayaan $95 \%$. 
Berdasarkan uji DMRT efek ekstrak kasar daun tumbuhan dengan taraf kepercayaan 95\% terhadap bakteri S. aureus, tampak bahwa perlakuancontrol menggunakan kloramfenikol dibandingkan dengan konsentrasi 15\%, $11.25 \%, 7.5 \%, 3.75 \%$, dan $0 \%$ menunjukkan adanya perbedaan. Perlakuan dengan konsentrasi 15\% pengaruhnya berbeda tetapi tidak signifikan dengan konsentrasi $11.25 \%$, $7.5 \%$, dan $3.75 \%$, akan tetapi konsentrasi $15 \%$ pengaruhnya berbeda signifikan dengan perlakuan konsentrasi $0 \%$. Perlakuan dengan konsentrasi $11.25 \%$ pengaruhnya berbeda tetapi tidak signifikan dengan konsentrasi $7.5 \%$, dan $3.75 \%$, akan tetapi konsentrasi $11.25 \%$ pengaruhnya berbeda signifikan dengan perlakuan konsentrasi 0\%. Perlakuan dengan konsentrasi $7.5 \%$ pengaruhnya tidak berbeda nyata dengan konsentrasi $3.75 \%$, akan tetapi konsentrasi $7.5 \%$ pengaruhnya berbeda signifikan dengan perlakuan konsentrasi 0\%. Perlakuan dengan konsentrasi $3.75 \%$ pengaruhnya berbeda signifikan dengan konsentrasi $0 \%$.

Gambaran perlakuan ekstrak kasar daun meranti tembaga ( $S$. leprosula Miq.) terhadap bakteri $S$. aureus dan E. Coli dapat dilihat pada Gambar 1 dan Gambar 2.

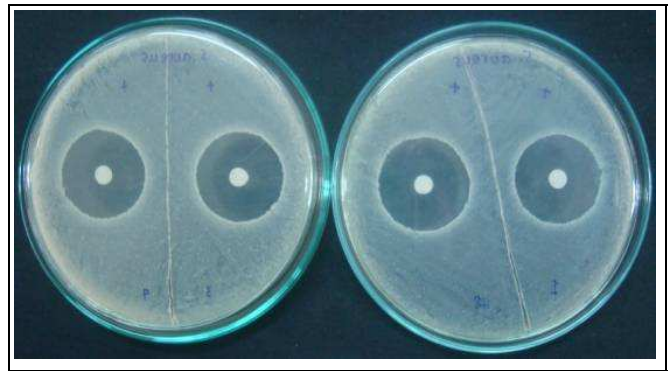

(a)

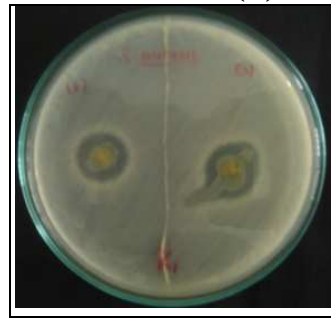

(c)

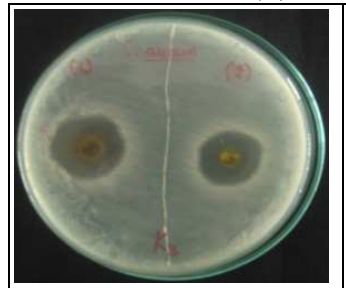

(e)

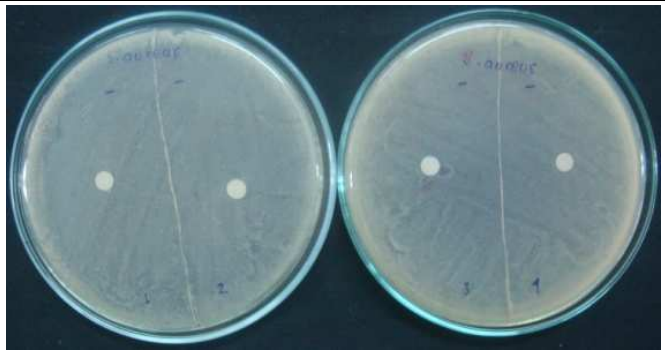

(b)

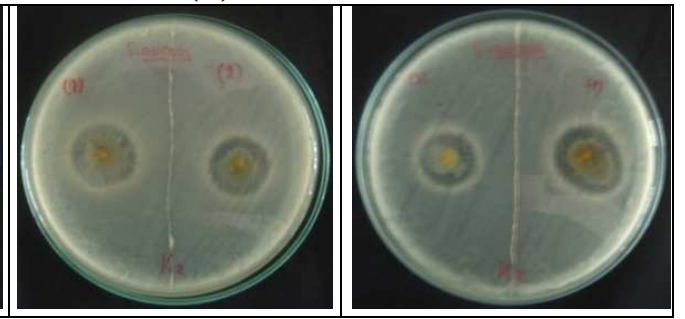

(d)

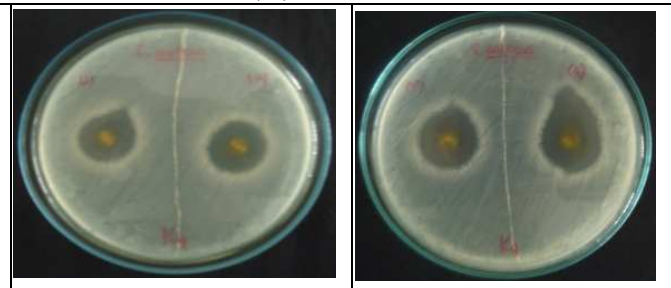

(f)

Gambar 1. Zona Hambat Perlakuan Ekstrak Kasar Daun Meranti Merah (S. leprosula Miq.) terhadap bakteri S. aureuspada konsentrasi (a) K+ (kloramfenikol), (b) 0\% (aquadest steril), (c) 3,75\%, (d) $7,5 \%$, (e) $11,25 \%$, dan (f) $15 \%$. 

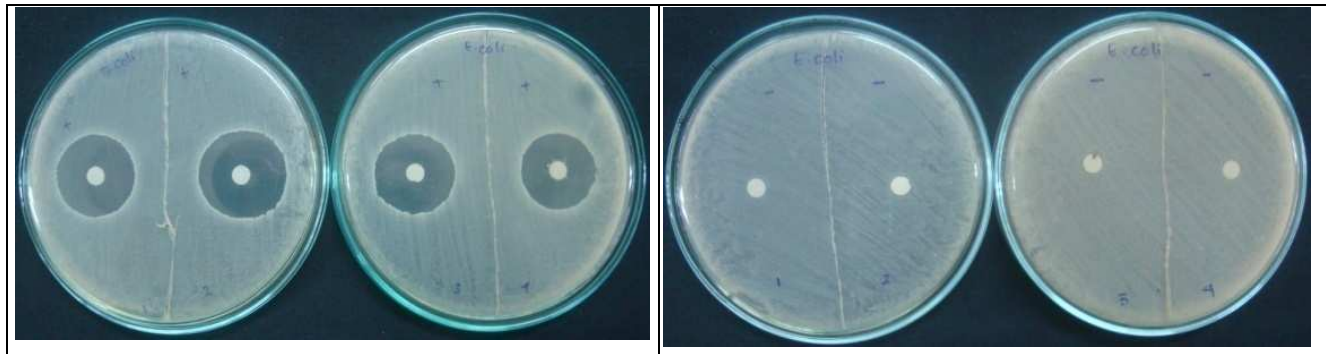

(a)

b)

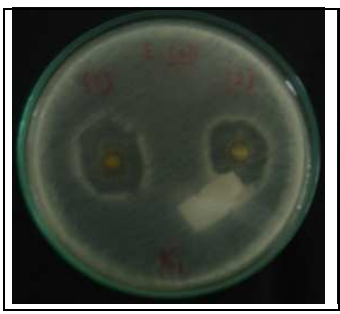

(c)

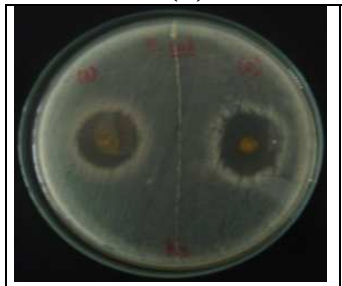

(e)
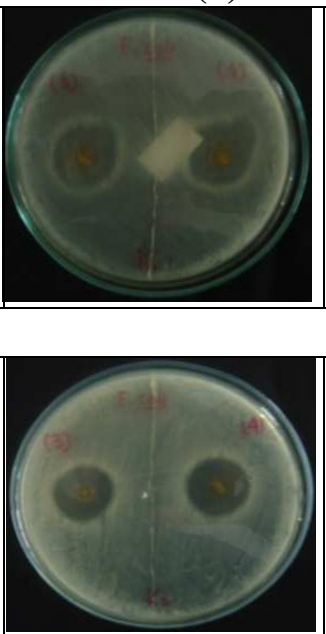

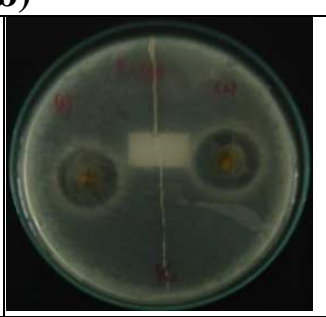

(d)

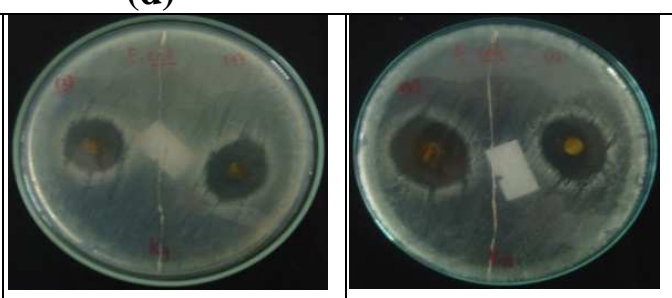

(f)

Gambar 2. Zona hambat perlakuan ekstrak kasar daun Meranti Tembaga (S. leprosula Miq.) terhadap bakteri E. coli pada konsentrasi (a) K+ (kloramfenikol), (b) $0 \%$ (aquadest steril), (c) 3,75\%, (d) $7,5 \%$, (e) $11,25 \%$, dan (f) $15 \%$.

Dari hasil pengamatan zona hambat terendah pada bakteri $S$. aureus adalah konsentrasi $3.75 \%$ dengan rata-rata diameter zona hambat $13.12 \mathrm{~mm}$, sedangkan tertinggi pada konsentrasi $11.25 \%$ dengan rata-rata diameter zona hambat $16.25 \mathrm{~mm}$. Pada bakteri E. coli diameter zona hambat terendah pada konsentrasi $11.25 \%$ dengan rata-rata diameter zona hambat $15.37 \mathrm{~mm}$, sedangkan tertinggi pada konsentrasi $15 \%$ dengan rata-rata diameter zona hambat $16.56 \mathrm{~mm}$. Dari nilai rata-rata zona hambat pada kedua bakteri tersebut jika dibandingkan terhadap criteria kekuatan zat antibakteri dalam Tabel 4, dapat dikatakan bahwa ekstrak kasar daun meranti tembaga memiliki sifat bakteri yang termasuk katagori kuat. Konsentrasi terbaik sifat antibakteri dari ekstrak kasar daun meranti tembaga terhadap bakteri $S$. aureus dan bakteri E. coli.adalah pada konsentrasi $15 \%$.

Secara umum, mekanisme kerja senyawa antibakteri dibagi dalam empat kelompok. Pertama, senyawa antibakteri menghambat sintesis dinding sel. Kedua, senyawa antibakteri menghambat metabolisme sel. Ketiga, senyawa antibakteri mengganggu keutuhan membran sel. Dan keempat, senyawa antibakteri menghambat sintesis protein dan asam nukleat [1]. 
Tabel 4. Klasifikasi kekuatan antibakteri ekstrak kasar daun meranti tembaga (S. leprosula Miq.) terhadap bakteri S. aureus dan bakteri E. coli.

\begin{tabular}{|c|c|c|c|c|c|}
\hline \multirow[t]{2}{*}{ Perlakuan } & \multicolumn{2}{|c|}{$\begin{array}{c}\text { Dimeter Zona Hambat } \\
(\mathbf{m m})\end{array}$} & \multicolumn{2}{|c|}{$\begin{array}{c}\text { Kekuatan } \\
\text { Antibakteri }\end{array}$} & \multirow[t]{2}{*}{ Indikator ** } \\
\hline & S. aureus & E.coli & S. aureus & E. coli & \\
\hline $0 \%$ & 0.00 & 0.00 & Lemah & Lemah & \multirow{6}{*}{$\begin{array}{l}\leq 5 \text { lemah } \\
6-10 \text { sedang } \\
11-20 \text { kuat } \\
\geq 21 \text { sangat kuat }\end{array}$} \\
\hline $3.75 \%$ & 13.12 & 16.43 & Kuat & Kuat & \\
\hline $7.5 \%$ & 14.75 & 16.43 & Kuat & Kuat & \\
\hline $11.25 \%$ & 16.25 & 15.37 & Kuat & Kuat & \\
\hline $15 \%$ & 15.56 & 16.56 & Kuat & Kuat & \\
\hline Kloramfenikol & 22.18 & 20.31 & Sangat kuat & $\begin{array}{l}\text { Sangat } \\
\text { kuat }\end{array}$ & \\
\hline
\end{tabular}

Keterangan **:Ardiansyah (2005)

Berdasarkan analisis fitokimia, senyawa metabolit sekunder yang terdeteksi pada daun meranti tembaga adalah alkaloid, saponin, triterpenoid, flavonoid, dan fenolik.Dengan demikian dapat diduga bahwa aktivitas antibakteri daun meranti tembaga berkaitan erat dengan adanya senyawa aktif yang terkandung didalamnya, dimana senyawa aktif tersebut dapat mengganggu metabolisme dalam bakteri sehingga pertumbuhan bakteri terhambat atau mati.

Menurut Gunawan (2008), keaktifan biologis dari senyawa alkaloid disebabkan oleh adanya gugus basa yang mengandung nitrogen. Adanya gugus basa ini apabila mengalami kontak dengan bakteri akan bereaksi dengan senyawa-senyawa asam amino penyusun dinding sel bakteri dan DNA bakteri yang merupakan penyusun utama inti sel yang merupakan pusat pengaturan segala kegiatan sel. Reaksi ini terjadi karena suatu senyawa yang bersifat basa akan bereaksi dengan senyawa asam, dalam hal ini adalah asam amino. Reaksi ini mengakibatkan terjadinya perubahan struktur dan susunan asam amino karena sebagian besar asam amino telah bereaksi dengan gugus basa dari senyawa alkaloid. Perubahan susunan asam amino ini akan mengubah susunan rantai DNA pada inti sel yang semula memiliki susunan asama dan basa yang saling berpasangan. Perubahan susunan rantai asam amino pada DNA akan menimbulkan perubahan keseimbangan genetik pada DNA sehingga DNA bakteri akan mengalami kerusakan. Kerusakan DNA pada inti sel bakteri ini akan mendorong terjadinya lisis pada inti sel bakteri. Lisisnya inti sel bakteri akan menyebabkan juga kerusakan sel pada bakteri sehingga bakteri akan menjadi inaktif dan mati.

Senyawa saponin dapat bekerja sebagai antimikroba dengan cara merusak membran sitoplasma dan membunuh sel.

Senyawa flavonoid diduga merusak dinding sel dari bakteri yang terdiri atas lipid dan asam amino. Senyawa yang terdapat dalam dinding bakteri ini akan bereaksi dengan gugus alkohol dari senyawa flavonoid sehingga dinding sel akan rusak danmenyebabkan senyawa tersebut dapat masuk kedalam inti sel bakteri. Selanjutnya senyawa ini akan bereaksi dengan DNA pada inti sel bakteri dan melalui perbedaan kepolaran antara lipid penyusun DNA dengan gugus alkohol pada senyawa flavonoid akan terjadi reaksi sehingga akan merusak 
strukrur lipid dari DNA bakteri sehingga inti sel bakteri akan mengalami lisis.

Senyawa triterpenoid diduga akan bereaksi dengan porin (protein transmembran) pada membran luar dinding sel bakteri membentuk ikatan polimer yang kuat sehingga mengakibatkan rusaknya porin. Rusaknya porin yang merupakan pintu keluar masuknya substansi, akan mengurangi permaebilitas dinding sel bakteri yang akan mengakibatkan sel bakteriakan kekurangan nutrisi sehingga pertumbuhanbakteri terhambat atau mati.

Menurut Naim (2004), senyawa fenol merupakan senyawa yang berfungsi sebagai antimikroba, dengan mekanisme penghambatan mikroba oleh fenol seperti merusak dinding sel sehingga mengakibatkan lisis/ menghambat proses pembentukkan dinding sel yang sedang tumbuh; mengubah permeabilitas membran sitoplasma yang menyebabkan kebocoran nutrien dari dalam sel; mendenaturasi protein sel; dan merusak sistem metabolisme didalam sel dengan cara menghambat kerja enzim intraseluler.

\section{KESIMPULAN}

Dari hasil analisis fitokimia dan daya antibakteri ekstrak kasar daun meranti tembaga ( $S$. leprosula Miq.) terhadap bakteri $S$. aureus dan $E$. coli dapat disimpulkan bahwa:

1. Kandungan senyawa metabolit sekunder ekstrak daun Tumbuhan Meranti Tembaga (S. leprosulaMiq.) terdeteksi terdiri atas kelompok senyawa alkaloid, saponin, triterpenoid, flavonoid, dan fenolik.

2. Ekstrak kasar daun meranti tembaga(S. leprosula Miq.) bersifat antibakteri terhadap bakteri E.colipada konsentrasi terendah $(3,75 \%)$ dengan nilai rata-rata diameter zona hambatan $16,43 \mathrm{~mm}$, dan termasuk kategori kuat. Sedangkan pada bakteriS. aureus konsentrasi terendah $(3,75 \%)$ dengan nilai rata-rata diameter zona hambatan 13,12 mm dengan kategori antibakteri kuat.

3. Konsentrasi terbaik sebagai antibakteri S.aureus dan E.colitelah ditunjukkan pada pemberian konsentrasi perlakuan terendah $(3,75$ $\%)$, yang menunjukkan sifat daya antibakterinya tidak berbeda nyata dengan konsentrasi di atasnya.

\section{SARAN}

1. Pada penelitian ini konsentrasi terbaik untuk menghambat pertumbuhan bakteri $S$. aureus dan bakteri $E$. Coli ditunjukkan pada konsentrasi terendah yakni $3.75 \%$. Disarankan penelitian selanjutnya menggunakan konsentrasi lebih rendah.

2. Perlu dilakukan uji lebih lanjut pada ekstrak daun meranti tembaga ( $S$. leprosula Miq.) sebagai antibakteri terhadap jenis bakteri lain yang dapat menyebabkan penyakit dengan menggunakan berbagai fraksi, seperti fraksi n-heksan, fraksi butanol, fraksi etil asetat, dan fraksi-fraksi lain yang mungkin untuk dilakukan.

\section{DAFTAR PUSTAKA}

1. Brooks, G.F.; Janet, S.B.; Stephen, A.M.; Jawetz; Melnick; \& Adelberg's. 2001. Mikrobiologi Kedokteran. Alih bahasa oleh Mudihardi, E.; Kuntaman; Wasito, E.B.; Mertaniasih, N.M.; Harsono, S.; \& Alimsardjono, L.; Jakarta: Salemba Medika.

2. Eun-Kyong, C.S.; Constan, H.L.; Santisuk, T.; Reutrakul, V.; Beecher, C.W.W.; 
Fransworth, N.R.; Cordel, G.A.; Pezzuto, J.M.; \& Knghorn, A.D. 1999. Resveratrol Tetramers from Vatica diospyroides. J. Org Chem 64: 6976-6983

3. Gunawan. 2008. Antibakteri pada herba Meniran (Phylanthus niruri Linn). Jurnal Kimia, Vol II (22), hal.31-39. http://www.google.com.Diakses pada tanggal 20 Januari 2012.

4. Harbone, J. B. 1987. Metode Fitokimia. Bandung: ITB.

5. Newman, M. F.; Burgess, P. F.; \& Whitmore, T. C. 1999. Pedoman Indentifikasi Pohonpohon Dipterocarpaceae Pulau Kalimantan. Bogor: Prosea Indonesia.
6. Pelezar, M.J.; \& Chan E.C.S. 2005. DasarDasar Mikrobiologi Jilid 1. Jakarta: Universitas Indonesia.

7. Sotheeswaran, S.; \& Pasupathy, V. 1993. Distribution of Resveratrol Oligomers in Plants. Phytocchemistry 53: 1015-1019

8. Sudjana. 1991. Desain dan Analisis Eksperimen. Bandung: Tarsito

9. Sultanbawa, M.U.S.; Surendrakumar, S.; \& Bladon, P. 1980. New Antibacterial Polyphenol Copalliferol A from Vateria Copallifera (Retz) Aslon (Dipterocarpaceae) J.C.S Chem Comm 619-620

10. Volk, W. A.; \& Wheeler, M. F. 1990. Mikrobiologi Dasar Edisi Kelima Jilid 2. Jakarta: Erlangga. 